\title{
TEACHERS' INTERPRETATION OF MATHEMATICS GOALS IN SWEDISH PRESCHOOLS
}

\author{
Laurence Delacour \\ Malmö University
}

\begin{abstract}
The purpose of this paper is to investigate how preschool teachers interpret the revised mathematics goals in the Swedish preschool curriculum. I analyze how some preschool teachers transform, clarify, and concretize those mathematical goals, with a focus on didactic questions related to content: What is preschool mathematics according to the teacher? How can mathematics be communicated? And why is mathematics communicated? I place the study within a curriculum didactic perspective. The key concept is Linde's (2006) classification of teachers' ways of approaching a subject. Most of the text is adapted from my thesis (Delacour, 2013).

Key words: preschool, preschool teacher, mathematics, curriculum
\end{abstract}

\section{Introduction}

National and international comparisons in recent years have emphasized ability in mathematics. For example, several studies (OCED, 2012) show that children in both Europe and the United States have difficulty succeeding in mathematics; consequently, there has been a more distinct focus on mathematics in preschools. The Swedish government believes that Swedish preschools have not made full use of children's desire to learn (Regeringskansliet, 2010). According to Tallberg-Broman (2012), there is a paradigm shift in Sweden today from which a new vision of children, parenting, and the school's mission is emerging. Consequently, preschool teachers have to help children meet an increasingly complex reality both now and in 
the future, and the professional skills required of preschool teachers have also increased (Persson \& Tallberg-Broman, 2002). In 2011, a revised preschool curriculum was introduced (Skolverket, 2010) in which the goals for children's mathematical development were made clearer in both scope and content. Currently, preschools must strive to ensure that each child develops, expresses, and uses his or her understanding of space, shape, location, direction, sets, quantity, order, number concepts, measurement, time, and change. Furthermore, each child should develop his or her ability to reflect, test solutions, and present and follow reasoning (Skolverket, 2010).

In this paper, I discuss a part of my thesis (Delacour, 2013) that is on preschool teachers' interpretation of the mathematical goals specified in the curriculum for preschool. By analyzing how preschool teachers talk about the mathematics objectives and how these objectives are transformed in practice, this study can provide valuable information about how the study of mathematics is visible in the preschool.

\section{The revised curriculum for preschool}

In the mission of Swedish preschools, caring, education, and learning form an integrated whole. Although the focus on caring is unchanged in the new document, more emphasis is placed on learning and knowledge (Vallberg-Roth, 2011). How children are to create, explore, and use mathematics is not specified in the curriculum, as it is a goal-oriented document without suggestions on how to teach. According to the curriculum, learning should start from children's development, experiences, interests, and circumstances and take place in a playful manner. The objectives are formulated as goals for the preschool to strive toward. There are no specific goals for the children to achieve because the approach is that preschoolers 
should not be assessed based on established standards and should not be compared to anyone other than themselves.

\section{Research questions}

The research questions for my thesis (Delacour, 2013) were these:: How do preschool teachers talk about the national curriculum objectives in mathematics with a focus on content and form? How are the national objectives for mathematics transformed in preschool teachers' planning and implementation of a mathematical situation? What didactic contracts emerge from preschool teachers in transforming the national objectives in mathematics? In this paper I focus on the first and second questions.

\section{The preschool teacher and mathematics}

According to Doverborg and Pramling Samuelsson (2011), everyday life at preschool provides many opportunities for children to encounter basic mathematical concepts, but teachers may not have sufficient knowledge about early childhood mathematics to be able to take advantage of these opportunities. Some educators believe that mathematics should only start to be taught at primary school levels (Doverborg \& Pramling Samuelsson, 1999). Palmer (2010) found that most students of early childhood teacher education were negatively disposed toward mathematics and linked this dislike to counting, math books, and sample calculations. Some preschool teachers prefer to focus on areas of language and literacy, where they feel safe; hence, they have no time for mathematics (Lee \& Ginsburg, 2009). The uncertainty about the subject might partially be attributed to the fact that there are different conceptions of what is meant by mathematics at preschools and a fear that preschool could become too much like primary school. 
An idea that seems prevalent among preschool teachers is that a preschooler learns by participating in everyday situations. Therefore, many educators believe that children are learning all the time and from everything (Bjorklund, 2007; Doverborg \& Pramling Samuelsson, 1999). Some educators believe that children discover mathematics in a natural way when they play games, build with Lego, or tidy up toys. However, the problem with these approaches is that it is usually the children who already have some knowledge and interest who get the most out of these activities (Ahlberg, 2000). Children learn independently to a certain extent, but according to Hildebrandt and Zan (2002), they must be challenged to think one step further and see things from different perspectives. Children can discover mathematics when teachers create an educational environment and when they take a step back and let the children play. The foundations of mathematics can be laid through activities such as building with sand, playing with water and various containers, or doing puzzles. However, in order to be able to build on these foundations and to be able to understand and put words into mathematical concepts, children need a teacher:

Free play can provide a useful foundation for learning, but a foundation is only an opportunity for building a structure. Adult guidance is necessary to build a structure on the foundation of children's informal mathematics (Hildebrandt \& Zan, 2002, p. 2).To be able to attain the curriculum and communicate around some specific mathematical concepts, it helps if the teacher focuses on the content; otherwise the content will be submerged beneath other material (Thulin, 2011).

\section{Theoretical framework}

In this section, I take up the didactic perspective of the study, highlighting briefly the didactic of mathematics, the curriculum theory of didactics, and the categorization of different teaching approaches. The key concept here is transformation. 
The didactic perspective

Didactics focuses on the content of education in general, while subject didactics focuses on education in relation to specific subject content (Kroksmark, 1989). I highlight the theory and practice of teaching on the basis of what should be taught, how it should be taught, and to some extent, why it should be taught in a certain manner (Gundem \& Hopmann, 2002). Traditionally, preschools in Sweden do not divide activities into subjects; instead, integrative didactics have been customary, where preschool teachers work with themes and subject-integrated activities. According to the curriculum, care, education, and learning should shape the activity (Skolverket, 2010), but how this fits in with subject didactics is not self-evident. Preschool needs a language that can make visible and problematize the new mission (Thulin, 2011) even though the use of the term "subject didactics" may affect preschool activities. Thulin believes that preschool teachers' perception of their mission is problematic in practice, because the focus is on care and education, while what should be learned remains unclear. Furthermore, she observes that there is a good possibility for implementing a changed knowledge mission in preschools where care, education, and learning form a whole.

If we are able to talk about the didactics of mathematics, it probably will help to make mathematics visible in Swedish preschools. When children help to set the table for a meal, for example, language, play, mathematics, care, and education can be integrated. Even in contexts like these, the preschool teacher should be able to focus on mathematics to better assist children in understanding mathematical concepts. However, subject didactics, in the case of younger children, focuses more on meaning creation and investigation than on children acquiring a given amount of knowledge (Lundgren, Säljö \& Liberg, 2010).

In this paper, I focus on the didactic questions "what?" and "how?" to highlight teachers' interpretation of the national objectives and the examples they give to 
illustrate their interpretation. By "what?" I mean the interpretation of what mathematics for young children is according to teachers' interpretation of the Swedish curriculum for preschools. When teachers talk about how they interpret the objectives for mathematics, they also give examples to illustrate how they transform these objectives into practice.

Broader curriculum concepts - curricular work as didactic activities

I situate the study in a curriculum didactic perspective (Gundem \& Hopmann, 2002) because the study focuses on preschool teachers' transformation of the national curriculum objectives for mathematics with a focus on content. There are many ways to discuss curriculum concepts and curricular work as didactic activities. The formally determined curriculum is interpreted at different levels and therefore is never identical for school politicians, administrators, teachers, parents, and children. In my study, the focus is on the perceived curriculum based on preschool teachers' narratives and their descriptions and transformations of the national objectives for mathematics. The curriculum is transformed in different ways; what preschool teachers choose to focus on will depend to some extent on the views they have of the preschool's mission. Transformation is unique for each actor and it is not an easy process (Linde, 2006).

Teachers' possible approaches

Linde (2006) classifies teachers' ways of approaching a subject in a small number of categories, and from these categories I developed my own interpretation on the basis of preschool teachers' activities that focused on mathematical content:

- Proximity-distance: The teacher may keep mathematics in readiness, preparing for a situation where she focuses on one or more mathematical concepts 
(i.e. mathematics as a goal) - or she may extend the mathematics concepts so they are included in a theme where mathematics is used to solve various problems (mathematics as a means).

- Deductive-inductive creation: The teacher may base a situation on one or more mathematical concepts - or may draw attention to mathematical concepts when they show up during a situation.

- Open-closed: The teacher may be open to issues and actions coming from the children - or may keep to the original plan for the lesson.

- Answer-problematization: The teacher may ask the children questions and help them find a correct response eventually - or she may let the children formulate their own questions and answers; she may not draw any conclusions, but rather show children the complexity of the situation and that there can be multiple answers.

- Intensity-extensity: The teacher may provide a lot of information immediately - or give the children plenty of time to solve various problems.

Linde's classification of teachers' way of approaching a subject has been reworked in this study to correspond with preschool activities. I have applied these classifications to the didactic perspective for mathematics.

\section{Method}

I conducted interviews with four preschool teachers to investigate how they discuss and interpret the national curriculum objectives for mathematics and to examine how they transform their interpretations into action. The teachers worked in two different preschools. They worked actively with mathematics in a group consisting of fouryear-old and five-year-old children. They had been working as preschool teachers for $9,15,22$, and 32 years. Two of them had attended mathematics courses at the 
university after taking their examinations because mathematics was not a part of the programme at the time of their initial education. The two others had not attended any mathematics courses. To answer my research questions, I interviewed the teachers individually. The interviews were semi-structured in order to be flexible, to allow the follow-up of ideas, and to ask supplementary questions (Bryman, 2011).

The preschools included in the study were located in two small communities of the same municipality. They showed no major differences in staff composition, group size, or children's socio-cultural and economic background.

\section{Analysis of the data}

To analyze and interpret the data, I used a hermeneutic approach (Bryman, 2011). My use of the approach was based partly on my experience as a preschool teacher, partly on theoretical perspectives, and partly on prior research that discussed preschool teachers' approach to mathematics for younger children. I made a reflexive interpretation of preschool teachers' stories and used an abductive analysis, which meant that I moved between data and theory analysis (Alvesson \& Sköldberg, 2010). In preschool teachers' talk, I found differences that I could categorize and then sorted my results under those categories.

\section{Teachers' possible approaches}

Since the mathematical objectives in the Swedish curriculum have no related instructions on methodology, they provide opportunities for several types of orientation. In my study, I found that preschool teachers' had different expectations of the relationships among children, teachers, and mathematics. In the analysis of the interviews, preschool teachers' interpretations of the mathematics objectives differ, leading to two separate ways of transforming the objectives in practice and 
indicating a tendency toward two different ways of communicating mathematics. One way is the tendency to be child-initiated (which I term CI); the other way is more teacher-initiated (TI). I applied these distinct approaches to Linde's (2006) classification of teachers' ways of approaching a subject.

\section{The child-initiated approach}

In the transformation of the mathematical goals applying a CI approach, preschool teachers gave examples of how mathematics are communicated by using mathematics as a means within a theme:

Lotta: We had ... Olle's "ski trip" from Elsa Beskow as the basis for the activities. Based on this, They built skis with milk cartons and made the skis as long as themselves ...

This statement may be linked to Linde's classification of "distance."

In the CI approach, mathematics is perceived by the body. This preschool teacher believes that children need to feel mathematics with their body, for instance, by walking a tightrope; feeling distance; seeing forms, colors, and numbers:

Susan: When they are young, it is important, from the beginning, to get the feeling of mathematics. What you learn with the body stays in your mind.

When the preschool teacher gives the children the opportunity to do these things, children will eventually understand once they are mature enough. In the CI approach, mathematics is about number concepts, shape, size, differences, but teachers do not expect the children to understand the concepts. The mathematical situations offered to the children are based on learning by doing:

Lotta: ... we help them to think and perhaps to come up with a thought or maybe not an answer but a little dialogue between us / ... / there is no right and wrong without the children themselves finding a comment or a discussion about how they think. 
The teachers talk about paying attention to mathematical concepts as and when they show up; this may be related to an "inductive" form:

Susan: ... it was the children who talked about shapes.... and we picked up on it ...

Preschool teachers start from children's interests and actions when they communicate mathematics; this may be linked to an "open" form:

Susan: ... We divide the children into groups based on their interests. / ... / the goal is that children's questions and thoughts are important, also their experiences. And, we discover together ...

Furthermore, children formulate their own questions and answers; this may be linked to Linde's category of "problematization."

Susan: It's not a matter of: "I am right!" For sometimes it's about what children are searching for. And what is it now? What should it be? It is not me that controls it. No, it's based on what they see. / ... / How do you think? Or how did it happen? / / they are free to arrive at their own solutions.

When children communicate at their own pace and in play, this behavior may be related to the category of "extensity." The preschool teacher communicates mathematics by offering opportunities to explore. The preschool teacher seems to have faith in the children's ability to seek knowledge and to learn from each other. That is, she expects the children to take an active part in the planning of the activity by showing and sharing interests among one another:

Susan: ...We communicate with each other and try to get kids to communicate together because they are curious, they want to learn. Lotta: ... they are good at finding the solutions to problems / ... / we think so, and the children themselves may find a comment or a discussion of how they think and that's real development ... 


\section{.The teacher-initiated approach}

In the transformation of the mathematical goals with a TI approach, mathematics at preschool is expressed as an easier form of primary school mathematics:

Åsa: I can say that when I worked in primary school, there was a lot of math. It was for slightly older kids, but I got a lot of benefit from it and here I take it down to the younger children's level, for four and five year olds.

Understandings of abstract concepts are central. Mathematics for children is about learning to recognize and name shapes and about understanding fractions and patterns; consequently, children should pay attention to differences and justify their answers. The preschool teacher works with concrete material, but the mathematical concepts she uses are sometimes abstract. The orientation she offers is based on cognitive skills:

Åsa: I will work a lot with the number $2 \ldots$. / / We' 11 continue to work with the circle and walk around. / ... / And then they'll hold up the longest stick .... and the shortest, and then I'll get them to hold up the thickest and the thinnest ...

The teachers talk about mathematics as a goal in itself; this may be linked to Linde's category of "proximity." The material contains examples where mathematics is chosen as the theme and mathematical situations initiated over a longer period. Mathematics is woven into everything, and themes can be concluded with a display. Mathematics as a theme was a decision that came from management.

Some preschool teachers keep mathematics in readiness and prepare situations where they focus on mathematical concepts and use mathematics as a goal:

Malin: ... I am always thinking about mathematics in my planning. / / I get into the language, I get into social interaction and collaboration, I get into more but it is still mathematics, that I have in mind... I focus on form, geometric shapes ... we went hunting, hunting for triangles, rectangles, squares, circles. We were out in the 
neighborhood, we talked about form, and we made diagrams on the board about where we found most of the forms ...

In preparation and teaching, a preschool teacher may start from certain mathematical concepts; she communicates mathematics by initiating situations in which the children can learn mathematical concepts by following the instructions and trying things in practice. When children follow every step of a process, they will form mental images and will thus be able to think abstractly, according to these preschool teachers:

Malin: ... Now we have new children so we get to start over, so it's also important to really show things: yes, we have a whole apple and to make it real, we show it and put it together and take it apart and put together again and so finally it sits there ... a quarter ... at Easter some children were able to understand "one sixteenth" when they shared clay ... because they had experienced the whole process of dividing it into parts ...

Åsa: ...We started with the abstract concept now because we found that they have become skilled. ... Surprisingly many do actually understand the abstract because we have worked in such a very concrete way before. They have mental images....

The preschool teacher's task is to evoke the children's interest in mathematics. The mathematical concepts are chosen based on what preschool teachers believe that children need. This may be related to Linde's "deductive" category:

Åsa: ... We can't just sit and wait for the children to show an interest in something, but we have to get them interested ... When I worked at primary school, children had a really really hard time with patterns and fractions and I think as we have worked so much with sixths and fourths, I hope there will be a noticeable difference in school ......

When a preschool teacher keeps to her lesson plan, answers children's questions, or helps them to find a correct answer, this approach may be linked to Linde's "closed" and "answer" categories (cf. Linde, 2006): 
Åsa: ... When they are going to lift up the right stick and it is hard and so they raise the left hand, I say : no, no, right right right right right right right and they do so, right right [showing with his voice and body how she helps children in a fun way].

In a TI approach, preschool teachers provide much information and determine the pace of the situation; this may be related to the category of "intensity":

Åsa: I like to use a lot at one time so I put out a lot of Lego pieces and said: "everything is about 4." So they had to choose which four Lego pieces they wanted and then they would lay them down so it would be as long a line as possible. We measured the length and then they would lay them down and turn the the Lego pieces so it was as short ... then they had to make it as high as possible ...

\section{Results}

In my study, I found that two of the preschool teachers had a tendency to work with what I called the CI approach. It is the children's behavior and interests that determine the mathematical concepts that will be addressed in a situation. Preschool teachers often think about which mathematical concepts they want to communicate but they let children control the content and introduce different concepts. Preschool teachers would prefer the children to get a holistic picture where mathematical concepts are communicated as being anchored to something familiar and understandable to them. The teachers, therefore, choose to use mathematics as a means within a theme. When children explore and eventually pay attention to mathematical concepts, they can find their own answers, reflect, and draw their own conclusions together with their teachers. The children reflect on what is happening and explain and justify to each other. There is much interaction among the children. Reflections and justifications are visible. Children are given plenty of time to discover at their own pace. 
Furthermore, I found that the other two preschool teachers had a tendency to work with what I called the TI approach. These preschool teachers select specific mathematical concepts based on what they think the children need to get in touch with and stick to it. The situation is started by introducing a mathematical concept that children should communicate about. The situation is not linked to a theme but mathematics is used as a target. Early childhood educators in the TI approach are sensitive to how the children are doing and how much they can handle in; they try using body language, facial expressions, and other presentations to communicate mathematics in a fun and exciting way. The teachers try to keep the children focused on what they have prepared and help each child to understand and find solutions with the help of other children who are doing better or who can lead the way. Their attitude is considered important so that children will not feel singled out and lose interest in math when they do not find the right answer. Furthermore, these teachers give many instructions and talk a lot. From the children's side, there is silent reflection. When children are asked to justify their answers, their arguments will be simple and there is a minimal verbal interaction among the children.

\section{Why mathematics?}

A good education, according to Biesta (2011), can be achieved when we focus learning in such a way as to balance qualification, socialization, and subjectivity. The revision of the curriculum for the preschool can be interpreted as a tendency of our time to strike a balance among these different orientations (Delacour, 2013). My interpretation of the results of the present study is that the preschool teachers I interviewed have different focuses. Qualification implies a focus on different aspects of mathematics. Socialization implies that children are socialized to see and use mathematics differently, which leads to more or less opportunity to use their own voices (subjectivity). In summary, my interpretation is that these preschool teachers 
have different views on their mission and why they are communicating mathematics to children in preschool.

\section{Qualification}

Knowledge of mathematical concepts is not so prominent in the CI orientation and it is left to the children to see if they choose to talk about these things. The TI orientation's focus on qualification is more prominent with a clear tendency toward excellence. The preschool teacher's focus is to control the situation to enable the children to achieve "basic skills" (cf. Ernest, 2000). The curriculum has a tendency to be transformed into goals to achieve, a setting where children's knowledge and skills are encouraged and rewarded. An understanding of how mathematics can be used is not as prominent and creativity tends to disappear.

\section{Socialization}

Based on the analysis of my empirical work, my interpretation is that the CI orientation focuses on children's socialization when they connect mathematics to a theme, in this case the environment. Preschool teachers want children to get a holistic view of mathematics and to understand how mathematics can be used to improve the environment. The children can get a positive and enjoyable experience of mathematics in the spirit of community, respect, and cooperation when they play and learn at their own pace. The teacher allows children to formulate their own questions and answers in order to show the complexity of mathematics. The mathematical concepts get attention as they appear, while the teacher is open to the children's actions and proposals. The children are assigned agency in the form of participation, codetermination, and influence (cf. Trondman, 2011). 
As for the TI orientation, my interpretation is that the preschool teachers' focus on socialization involves the children experiencing mathematics as fun and interesting, while the teachers themselves try to make the subject fun and interesting. The children are socialized to consider mathematics as important to their future achievements in school, while their teachers tell them how good they are, and that they already know things that primary school children have not yet learned. These preschool teachers try to create a climate where children are allowed to think, dare, try, or even guess. Children should listen to each other and show respect for each other's answers, but I see a stronger connection to excellence in the TI orientation, where teachers who talk about the purpose of creating such an environment help children to challenge themselves.

\section{Subjectivity}

In the observations I made of these preschool learning situations, I see signs of two different approaches to subjectivity. In the CI orientation, my interpretation is that teachers' expectations are for children to become actors in their own learning; they should take the initiative and seek their own answers, consider their friends' solutions and the differences as several possible ways to solve problems. The children's self-confidence in mathematics is strengthened by not just considering their responses as being either right or wrong. Children have an innate potential that can be expressed and made available for the construction of a better society. Children have to take a lot of responsibility for their own education. In the CI orientation, the children seem to be given the opportunity to meet otherness and differences and thus be able to develop a unique voice.

In the TI orientation, my interpretation is that the teachers' expectations imply an ambition for the children to fully use their capacity to challenge themselves. They will be competitive but show respect for those who may achieve less. Teachers will 
accept a lot of responsibility for the children's education. The children's selfconfidence in mathematics will be enhanced when they feel they are allowed to "try it out" until they find the right answer. They should be able to have their own opinions and stand by them. Nevertheless, they will be given a greater opportunity to be heard with representative voices rather than with a unique voice.

\section{Conclusions}

Children need to come in contact with many experiences of different concepts in different contexts and have them illustrated in different ways. Concrete materials and a range of media should be used to support children in their understanding of abstract concepts; but enabling them to concretize the abstract can also contribute to concept development. Children can learn to solve many problems when they play and express mathematical concepts through play (Doverborg \& Pramling Samuelsson, 2011). Alrø and Johnsen-Høines (2010) argue that the quality of communication between teachers and children affects the quality of learning mathematics. They mean that an investigative approach to mathematics education is important for children to develop innovative skills and critical thinking. For instance, the areas of mathematics that young children learn quickly and early are the areas that are most "validated" socially, namely, number rhymes first, then counting, according to Brissiaud (2007). But it is harder for children to understand things that they never investigate at home, such as the type of information that is obtained when they count. What can it be used for? Would it be the same if we counted from right to left instead of left to right, if we symbolized the number ten with small plastic animals, or would it be the same number if we used ten little buttons instead? Brissiaud thinks it is mainly points like these that should be emphasized in preschool because children will face this type of issue only at preschool, while all children will meet number rhymes and counting at home, even in disadvantaged homes. Alrø and Johnsen-Høines (2010) observe that it 
can be difficult for children to take responsibility for their answers and be active if they only participate in evaluating talk aimed at determining what is right or wrong.

In conclusion, as I observed at the beginning of this paper, there is a paradigm shift in preschool mathematics in Sweden today. How mathematics should be communicated with respect to the Swedish preschool tradition, where play and children's interests are central, is not evident. The purpose of a curriculum is not to try to get everyone to do the same; nor is it the objective of research to show how the curriculum should be transformed. I hope that my study can provoke thought and reflection on what it is we want to achieve when we communicate mathematics in preschool. A greater awareness of the different ways of communicating mathematics can affect how children are qualified, socialized, and subjectified.

The approach that the preschool teacher prioritizes can be the beginning of a fruitful discussion about the preschool's future; currently, as in every paradigm shift, this is a period of hesitation and experiment. According to Deliyianni et al. (2009), formal mathematics teaching at early ages can get in the way of children thinking for themselves. When teachers give a more realistic, real-world presentation of problems, problems that need more careful consideration and offer alternative responses, pupils will tend to pay attention to the real meaning of the facts described in the problems (Verschaffel et al. 2000).

In the TI approach, the children are often required to give a correct answer to a problem and reach a solution by combining all the givens of the problem. An understanding of how mathematics can be used is not as prominent. Even if teachers present the situation in an amusing way, they still teach formal mathematics. In the $\mathrm{CI}$ approach, children do not always get the answers to their questions and it is left to them to see if they can perhaps talk through the mathematical concepts; nevertheless, they have been given the opportunity to think for themselves. In a future paper, I 
intend to investigate how informal and formal mathematics teaching affects preschoolers' mathematical development.

\section{REFERENCES}

Ahlberg, A. (2000). Att se utvecklingsmöjligheter i barns lärande. Matematik från början. Göteborg: Göteborgs universitet. Nationellt centrum för matematikutbildning.

Alrø, H. \& Johnsen-Høines, M. (2010). Critical dialogue in mathematics education. In H. Alrø, O.R. Christensen \& Valero,P. (Eds.) Critical Mathematics Education: Past, present and future. (11-22). Rotterdam: Sense Publishers.

Alvesson, M. \& Sköldberg, K. (2010). Tolkning och reflektion: Vetenskapsfilosofi och kvalitativ metod. Lund: Studentlitteratur AB.

Biesta, G. (2011). God utbildning i mätningens tidevarv. Stockholm: Liber.

Björklund, C. (2007). Hållpunkter för lärande: småbarns möten med matematik (dissertation). Åbo: Åbo Akademis förlag.

Brissiaud, R. (2007). Premiers pas vers les maths: Les chemins de la réussite á l'école maternelle. Paris: Editions Retz.

Bryman, A. (2011). Samhällsvetenskapliga metoder. Lund: Studentlitteratur.

Delacour, L. (2013). Interpreting the curriculum: Mathematics and didactic contracts in Swedish preschools. Utbildning \& Lärande, 6(2), 64-78.

Deliyianni E., Monoyiou A., Elia I., Georgiou C., \& Zannettou, E. (2009). Pupils' visual representations in standard and problematic problem solving in mathematics: Their role in the breach of the didactical contract. European Early Childhood Education Research Journal, 17(1), 95 - 110. 
Doverborg, E. \& Pramling Samuelsson, I. (1999). Förskolebarn i matematikens värld. Stockholm: Liber.

Doverborg, E. \& Pramling Samuelsson, I. (2011). Early mathematics in the preschool context. In N. Pramling \& I. Pramling Samuelsson (Eds.). Educational encounters: Nordic studies in early childhood didactics. Dordrecht, the Netherlands: Springer.

Ernest, P. (2000). Why teach mathematics? In S. Bramall \& J. White (Eds.), Why learn maths? (pp. 1-14) London: Bedford Way Papers.

Gundem, B.B. \& Hopman, S. (2002). Didaktik and/or Curriculum:An international dialogue. New York: Peter Lang Publishing, Inc.

Hildebrandt, C., \& Zan, B. (2002). Using group games to teach mathematics. In R. DeVries (Ed.), Developing constructivist early childhood curriculum: Practical principles and activities (pp. 193-208). New York: Teachers College Press.

Lee, Y.S. \& Ginsburg, H P. (2009). Early childhood teachers' misconceptions about mathematics education for young children in the United States. Australasian Journal of Early Childhood. 34(4), 37-45.

Linde, G. (2006). Det ska ni veta! En introduktion till läroplansteori. Lund: Studentlitteratur.

Lundgren, U P, Säljö, R, \& Liberg, C (Eds.). (2010). Lärande Skola Bildning: Grundbok för lärare. Stockholm: Natur \& Kultur.

Organisation for Economic Cooperation and Development (OECD) (2012). Starting Strong III - A Quality Toolbox for Early Childhood Education and Care. Elektroniskt tillgänglig, 2013-02-14. http://www.stofnanir.hi.is/rannung/sites/files/rannung/Starting\%20Strong\%20III. pdf 
Palmer, A. (2010). Att bli matematisk: Matematisk subjektivitet och genus $i$ lärarutbildningen för de yngre åldrarna. (dissertation). Stockholm: Pedagogiska institutionen, Stockholms universitet.

Persson, S. \& Tallberg Broman, I. (2002). Det är ett annat jobb: förskollärare, grundskollärare och lärarstuderande om professionell identitet i konflikt och förändring. Pedagogisk forskning i Sverige (7)4.

Regeringskansliet, utbildningsdepartementet, arbetsgrupp (U 2010: A), promemoria, 2010-06-24,U2010/4443/S. Elektroniskt tillgänglig 2013-02-14.

Skolverket. (2010). Curriculum for the preschool Lpfö 98, revised 2010. Stockholm: Fritzes.

Tallberg Broman, I. (2012, January). New challenges in ECEC - The paradigmatic shift. Paper presented at ICSEI, Malmö University, Sweden.

Thulin, S. (2011). Lärares tal och barns nyfikenhet. Kommunikation om naturvetenskapliga innehåll i förskolan (dissertation). Växjö: Växjö University Press.

Trondman, M. (2011). Snälla fröknar- om barns perspektiv och barnperspektiv. In I. Tallberg Broman (Eds.). Skola och barndom. Normering, demokratisering, individualisering (pp. 67-80). Malmö: Gleerups.

Utbildningsdepartementet (National Agency for Education) (2010). Förskola $i$ utveckling, bakgrund till ändringar i förskolans läroplan. Solna: Åtta 45.

Utbildningsdepartementet (2010). Regeringskansliet, promemoria, U2010/4443/S.

Vallberg Roth, A.C. (2011). De yngre barnens läroplanshistoria - didaktik, dokumentation och bedömning i förskola (2:a uppl.). Lund: Studentlitteratur.

Verschaffel, L., Greer, B., \& De Corte, E. (2000) (Eds.). Making sense of word problems. Lisse, The Netherlands: Swets and Zeitlinger. 
